\title{
Diacronie
}

Studi di Storia Contemporanea

$\mathrm{N}^{\circ} 30,2$ | 2017

Ponti fra nazioni e continenti

\section{Spy and Counterspy as a "Cultural Hero" in the Soviet Cinema of the Cold War}

\author{
Viktoria A. Sukovataya
}

\section{(QpenEdition \\ Journals}

\section{Electronic version}

URL: http://journals.openedition.org/diacronie/5689

DOI: $10.4000 /$ diacronie. 5689

ISSN: 2038-0925

\section{Publisher}

Association culturelle Diacronie

\section{Electronic reference}

Viktoria A. Sukovataya, «Spy and Counterspy as a "Cultural Hero" in the Soviet Cinema of the Cold War », Diacronie [Online], №30, 2 | 2017, document 3, Online since 29 July 2017, connection on 19 April 2019. URL : http://journals.openedition.org/diacronie/5689; DOI : 10.4000/diacronie.5689 


\section{Diacronie}

Studi di Storia Contemporanea

30, 2/2017

Ponti fra nazioni e continenti: diplomazia, immaginari e conoscenze tecniche

\section{Spy and Counterspy as a "Cultural Hero" in the Soviet Cinema of the Cold War}

Viktoria A. SUKOVATAYA

Per citare questo articolo:

SUKOVATAYA, Viktoria A., «Spy and Counterspy as a "Cultural Hero" in the Soviet Cinema of the Cold War», Diacronie. Studi di Storia Contemporanea : Ponti fra nazioni e continenti: diplomazia, immaginari e conoscenze tecniche, 30, 2/2017, 29/7/2017,

URL: < http://www.studistorici.com/2017/07/29/sukovataya_numero_30/ >

Diacronie Studi di Storia Contemporanea $\rightarrow$ http://www.diacronie.it Rivista storica online. Uscita trimestrale.

redazione.diacronie@hotmail.it

Comitato di direzione: Naor Ben-Yehoyada - João Fábio Bertonha - Christopher Denis-Delacour - Maximiliano Fuentes Codera Anders Granås Kjøstvedt - John Paul Newman - Deborah Paci - Niccolò Pianciola - Spyridon Ploumidis - Wilko Graf Von Hardenberg

Comitato di redazione: Jacopo Bassi - Luca Bufarale - Gianluca Canè - Fausto Pietrancosta - Alessandro Salvador - Matteo Tomasoni Diritti: gli articoli di Diacronie. Studi di Storia Contemporanea sono pubblicati sotto licenza Creative Commons 3.0. Possono essere

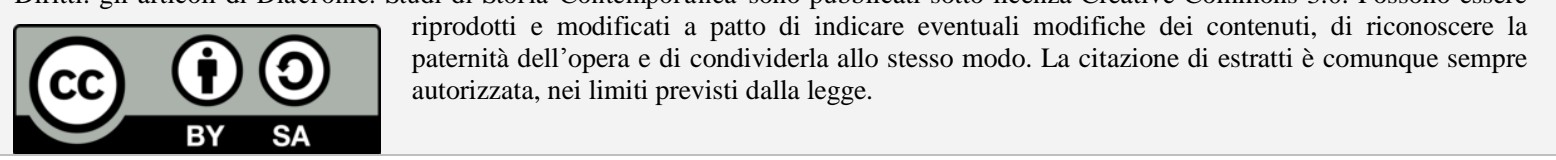




\title{
3/ Spy and Counterspy as a "Cultural Hero" in the Soviet Cinema of the Cold War
}

\author{
Viktoria A. SUKOVATAYA
}

This article aim to analyze the evolution of the Soviet spy cinema of the Cold War in the context of the cultural history and the social changes in the USA and the Soviet Union, and the relations with the political opponents. The public reception of the Soviet spy and spying was evolved in the Soviet Union and it was reflected in the cinema plots and characters transformations.

\section{Introduction: Cold War as a cultural epoch}

Recent academic and public interest in the cultural studies of the Cold War has become one of the main trends in the study of the Cold War for last decades ${ }^{1}$. There appeared an opportunity to research the Cold War not as a military confrontation of two political blocs but as a conflict of cultural ideas and images. As T. Shaw writes ${ }^{2}$, the tensions between East and West were institutionalized in the cultural production of the Cold War and due to television and cinema penetrated in hearts and minds of American and Soviet people.

The mutual distrust and public fears of a possible hegemony of the ideological and cultural "Other" have generated plots, among which the most representative genres in Western cinematography became the anti-communist films, the film noir, spy detective, horrors, and fantasies about "nuclear apocalypses". The Cold War cultural production had some national specific features in different countries and while the significant part of the Western (American

\footnotetext{
${ }^{1}$ WHITFIELD, Stephen, The Culture of the Cold War, Baltimore, Johns Hopkins University Press, 1996; HIXSON, Walter, Parting the Curtain: Propaganda, Culture, and the Cold War, 1945-1961, Basingstoke, Palgrave Macmillan, 1997.

${ }^{2}$ SHAW, Tony, Negotiating the Cold War in Film. The Other Side the Hollywood's Cold War: Images of Dissent in the 1950s, in HOLLOWAY, David, BECK, John (eds.), American Visual Cultures, London - New York, Continuum, 2005, pp. 133-141.
} 
and Western European) cinema during the Cold War was focused on the nuclear fears and atomic apocalypses ${ }^{3}$, the Soviet cinema of the Cold War did not create the nuclear fantasies: the Space and "the peaceful atom" were presented as the "friendly" substances in the Soviet popular culture. The Soviet people was proud of space and military achievements of the Soviet country: launching the first artificial satellite "Sputnik" (1957) and putting the first human into orbit, the Soviet cosmonaut Yuri Gagarin (1961). In the 1953 the Soviet Union tested the world's largest hydrogen bomb, but the military-technological experiments stimulated not atomic phobias in the Soviet mass consciousness but the development of the science fiction genre in the Soviet popular culture. Despite the fact that the discourse of the Soviet science fiction also contained the tropes of the Cold War, one should consider the spy movie as the most representative genre of the Cold War ${ }^{4}$, because it reflected the basic cultural notions of that epoch about the complicated opposition between the Soviet and the Western societies in the greatest degree. The spy detective in the Soviet popular culture represents the Soviet undercover agents as the "invisible defenders" of the Soviet state and the Soviet citizens against its external and internal enemies whose attempts "to penetrate the borders of the Soviet state": the slogan "people, to stay on alert!" was a common phrase of the Soviet Cold War propaganda in 1950-1960s.

In spite of the popularity of the spy movie in the Soviet Cold War the common opinion was that the spy detectives were products primarily of Western mass culture and the Western antiSoviet hysteria, the spy detective in the Soviet cultural studies was referred to the "low genres", a kind of "pulp fiction". My opinion is that although the Western term "spy movie" was not widespread in the Soviet cultural studies, the spy genre was a very influential direction in the Soviet popular culture during the Cold War because it met the demands of both entertainment and ideological functions. While the monotonous Soviet everyday life with a number of official rules and regulations, limited entertainment possibilities and spreading "occupation novels" in a socialist realism style, the spy detectives appeased hunger of the mass audience in bright adventures, discovering the inner mechanism of the political intrigues and necessary individualism of any secret agent (which was opposed to the official Soviet "mass collectivism" and which was not encouraged in the official Soviet rhetoric). An other specific feature of Soviet cultural discourse was that the Soviet intelligence officer was always titled as "intelligence man" (razvedchik, similar with "investigator" in Russian semantic), with completely a positive sense, whereas the word "spy" had only a negative meaning and was indicated any foreign agent, a foe, who worked against the Soviet state or the Soviet people at any level.

\footnotetext{
${ }^{3}$ KUBRICK, Stanley, Dr. Strangelove or: How I Learned to Stop Worrying and Love the Bomb, Hawk Film, USA, United Kingdom, 1964, 94'; BRICKMAN, Marshall, The Manhattan Project, 20th Century Fox, USA, 1986, 117'; and many others.

${ }^{4}$ HEPBURN, Allan, Intrigue. Espionage and Culture, New Haven - London, Yale University Press, 2005.
} 
The popular culture and movie of the Cold War have been studied quite extensively in the West ${ }^{5}$ for the last decades, but the Soviet popular culture and especially the Soviet spy films were not examined in the Soviet time, and they were studied partly in the contemporary Russia ${ }^{6}$. The first monographs on the Cold War cinema in the Soviet Union were published in the West after 1990s as the result of the rethinking Cold War ideological oppositions ${ }^{7}$. While the period under Stalin's rule can be considered in the context of totalitarian relations as the obvious tension between state and freedom ${ }^{8}$, the later socialist period after the Stalin's death can be not interpreted in the same way. Many contemporary Western scholars changed their opinion about the Soviet culture as something "prim, boring and rigid" and tried to delve the different Soviet decades into the cultural anthropology ${ }^{9}$. For example, American scholar Katerina Clark analyzed the Soviet culture as evolution of a certain number of archetypes which were dominant at the different socio-historical periods of the Soviet culture ${ }^{10}$. Other investigators put Soviet cinema in the comparative cultural perspective ${ }^{11}$. However, either Western or Russian studies of the Soviet Cold War culture were not focused on the Soviet spy films as a mirror of the Soviet public moods of the Cold War time.

The goal of my paper is to analyze evolution of the Soviet spies' images in the Soviet cinema not only in its poetic perspectives, but in the cultural atmosphere of the Cold War and political context of the Soviet Union's secret service operations. Also, I would like to define how the Soviet

\footnotetext{
${ }^{5}$ For example, HOBERMAN, James, An Army of Phantoms: American Movies and the Making of the Cold War, New York - London, New Press, 2012; SHAW, Tony, Hollywood's Cold War, Cambridge, Cambridge University Press, 2007.

6 ТУРОВСКАЯ, Майя, «Фильмы “холодной войны"» [TUROVSKAYA, Maya, «"Cold War" films»], in Искусство кино, 9, 1996, pр. 98-106; ФЕДОРОВ, Александр, «Холодная война на экране. Образы холодной войны: проекция политики противостояния на экране» [FEDOROV, Aleksandr, «Cold war on the screen. Images of the Cold War: the projection of a policy of confrontation on the screen»], in Полис, 4, 2010, pp. 48-64; СЕКИРИНСКИЙ, Сергей, «Советские реалии в зеркале телесериала "Семнадцать мгновений весны"» [SEKIRINSKY, Sergey, «Soviet reality in the mirror of the television series "Seventeen Moments of Spring"»], in Россия и современный мир, 40, 3/2003, pp. 148-160.

7 STITES, Richard, Russian popular culture. Entertaiment and society since 1900, Cambridge, Cambridge University Press, 1994; STRADA, Michael, TROPER, Harold, Friend or Foe? Russians in American Film and Foreign Policy, 1933-1991, Lanham, Scarecrow Press, 1997; WOLL, Josephine, Real Images: Soviet Cinema and the Thaw, London, Victoria House, 2000; BEUMERS, Birgit. Popular Culture Russia!, Santa Barbara - Denver - London, ABC Clio, 2005; YOUNGBLOOD, Denise, SHAW, Tony, Cinematic Cold War: The American and Soviet Struggle for Hearts and Minds, Lawrence, University Press of Kansas, 2010.

${ }^{8}$ KENEZ, Peter, Cinema and Soviet Society: From the Revolution to the Death of Stalin, London, I.B. Tauris, 2001; LAURENT, Natacha, L'œil du Kremlin. Cinéma et censure en URSS sous Staline, Toulouse, Privat, 2000.

${ }^{9}$ SUNY, Ronald Grigor, Reading Russia and the Soviet Union in the twentieth century: How the 'West' wrote its history of the USSR, in SUNY, Ronald Grigor (ed.), The Cambridge history of Russia, vol. 3, The Twentieth century, Cambridge, Cambridge University Press, 2006, pp. 5-64; DOBSON, Miriam, «The Post-Stalin Era: DeStalinization, Daily Life, and Dissent», in Kritika, 12, 4/2011, pp. 905-924; BEUMERS, Birgit, A History of Russian Cinema, New York, Berg Publishers, 2009.

${ }^{10}$ CLARK, Katerina, The Soviet Novel. History as Ritual, Bloomington (IN), Indiana University Press, 2000.

${ }^{11}$ GRAFFY, Julian, Scant Sign of Thaw: Fear and Anxiety in the Representation of Foreigners in the Soviet Films of the Khrushchev Years, in HUTCHINGS, Stephen (ed.), Russia and its Other(s) on Film: Screening Intercultural Dialogue, New York, Palgrave Macmillan, 2008, pp. 27-46.
} 
spies were connected with ideological construction of the "ideal Soviet person", and how the Soviet spies' images were evolved during decades of the Cold War. The actuality of the my studies is stipulated also by the fact that the Soviet mass culture of the Cold War (and even post-Soviet culture) was extremely sensitive and perceptive towards the feats of the Soviet agents both during the World War II and during the Cold War time. Many literary and cinema spies-characters became the "cult" figures in the Soviet mass consciousness and continue to be presented in the contemporary Russian everyday discourses and public rhetoric. The Soviet spy in the public mind was often presented as a "true knight", a hero without fear and beyond reproach, symbolizing the best masculine qualities: a valiant warrior, defender of the fatherland and intellectual. The image of a Soviet intelligence officer who fights against the Nazis in the enemy's rear conceptualized the Soviet notions of "inner" heroism very much, courageous but invisible heroism that was different from the heroism on the battlefield. I plan to analyze the Soviet spy films not at the level of their aesthetic value, but according to the ideas of L. Drummond ${ }^{12}$ and some American anthropologists ${ }^{13}$ about the cultural politics who consider the cultural texts (cinema, in particular) as the "authentic" reflection of the political, socio-cultural and everyday situation in a particular society, the ordinary life, talks and common humor that were typical for some society or its cultural groups in some historical period. Also I use semiotic analyses ${ }^{14}$ and visual art critique ${ }^{15}$.

\section{Nikolai Kuznetsov and a cult of a fearless agent in the Soviet post-war movie}

The most representative spyware Soviet detective of the first post-war decade was the film Secret Agent ${ }^{16}$ which was popular in the Soviet (especially, teenagers') audience for the several Cold War decades because it presented a very dynamic, adventurous plot and the patriotic character. The film was devoted to the fate of the semi-legendary Soviet spy-saboteur Nikolai Kuznetsov, operating on the territory of Western Ukraine during the Nazi occupation. The true and the most successful Kuznetsov's sabotage operations in 1943-1944 included execution of the German officers of the highest ranks: German Oberfuhrer Alfred Funk, Deputy Governor of Galicia District

\footnotetext{
${ }^{12}$ DRUMMOND, Lee, American Dreamtime: A Cultural Analyses of Popular Movies, New York: Littlefield Adams, 1996.

${ }^{13}$ GAYLES, Jonathan, BIRD, Elizabeth, Anthropology at the Movies, in HOLLOWAY, David, BECK, john (eds.), op. cit., pp. 284-290.

${ }^{14}$ UMBERTO, Eco, The Narrative Structure of Ian Fleming, BENNETT, Tony. (ed.), Popular Culture: Past and Present, Kent, The Open University, 1981, pp. 242-262; LOTMAN, Jury, USPENSKY, Boris, «On the Semiotic Mechanism of Culture», in New Literary History, 9, 2/1978, pp. 211-232.

${ }^{15}$ NOCHLIN, Linda, The politics of vision: essays on nineteenth-century art and society, New York, Harper \& Row, 1991.

${ }^{16}$ BARNET, Boris, Secret Agent, Dovzhenko Film Studio, USSR, 1947, 87’.
} 
Otto Bauer, General Inspector of Commissariat of the Rovno region Adolf Winter, Major General Max Ilgen. Kuznetsov also became famous in the post-war Soviet culture as the first Soviet agent who uncovered the German plans to launch a massive tank attack in the Kursk region (1943) and he transmitted that secret information about the Hitler's plan to kill the heads of the USSR, USA and Great Britain during the Tehran Conference (1943) to the Soviet Intelligence Office. Kuznetsov was posthumously awarded with the title of Hero of the Soviet Union, the highest military honor, however he continues to be a mysterious figure in the post-Soviet war history and provokes many discussions in the post-Soviet culture ${ }^{17}$. In spite of his semi-legendary personality and popularity in the Soviet mass culture, many facts of his biography are unknown to the wide audience until now.

In the first post-war decades there were published several novels and Soviet partisans' memories about their contacts with Nikolai Kuznetsov during the war and about his charismatic personality, and the Soviet mass mythology turned Nikolai Kuznetsov into a kind of "the icon", in the exemplary spy and infiltrator of the highest level. Even post-Soviet Russia shot a TV series devoted to the fate and the anti-Nazi activity of Nikolai Kuznetsov and many documentaries. However, in fact, Kuznetsov became known to the wide Soviet post-war audience only because his spy's cover was blown by the Germans and his final fate (death or survival) still causes discussions. But, apart from Nikolai Kuznetsov, there were several Soviet deeply secret agents during the war who having phenomenal skills of spying and being as Germans in appearance, were transferred into the German rear with their various life legends for sabotage against Nazis. Most of them and their activities are still unknown to the mass audience. Only during last decades there were shot several artistic films and TV series devoted to the hard fates of the Soviet spies and diversionists in the war and the pre-war time ${ }^{18}$. Despite the fact that they were the artistic films they demonstrated the elements of the complex professional and emotional training of the Soviet agents which were in secret during the Soviet decades.

A Soviet spy "under cover" Kuznetsov posed himself as an agent with many faces and names, but having a "true Aryan appearance" - blue eyes, blond hair and a straight nose, and mastering German language perfectly - he presented himself mostly as a German Oberleutnant Paul Siebert or Rudolf Schmidt from Berlin, and he acted in the German environment all the time. The dramatic episodes in that film were interleaved with comic ones (especially in the portraying of arrogant and self-satisfied Germans, realized themselves as the "master race" in the Soviet lands during the Nazi occupation). It is not surprising that Nikolai Kuznetsov became a "cultural hero"

\footnotetext{
${ }^{17}$ ГЛАДКОВ, Теодор, Кузнецов: легенда советской разведки [GLADKOV, Teodor, Kuznetsov: the legend of Soviet intelligence], Москва, Вече, 2004.

18 ATANESYAN, Aleksandr, Bastards, Russia, 2006, 94'; MOROZ, Uruj, Apostle, Russia, 2008, 600'; HYDOJNAZAROV, Bahtijor, The Hetaeras of Major Sokolov, Russia, 2014, 392'.
} 
in the early post-war Soviet culture, because his bold, smart and successful operations in the Soviet post-war film could play compensatory emotional function in the Soviet mass consciousness, in the country which experienced the bloody war and the brutal Nazi occupation of the Soviet territories just several years ago. Of course, the first Soviet post-war film about the spies greatly simplified the agent's psychology and all interrelations between Soviet agents, their subagents from locals and non combat population of Nazi-occupied territories. However, picturing dramatic details of the Soviet agent's activity in the film was not required in the postwar Soviet audience: the just ended war and the Nazi occupation were so traumatic for the Soviet people that many people were not ready to see the dramatic reality on the screen. Therefore, the early post-war Soviet spy films created a kind of fairy tale about fearless Soviet agents who acted as mythological epic heroes or powerful magicians. Namely such fearless and invulnerable character should present the "heroic spirit" of the Soviet people during the war in mind of the Soviet post-war audience which continued to mourn about its killed twenty seven millions Soviet sons and daughters.

\section{Soviet spy films of the "Thaw" and attempts to reflect the hot issues of the Soviet society}

The ideological confrontation of the "Communist East" and the "bourgeois" West was absent in the early post-war Soviet films about the spies, and there were several reasons for that. The first Soviet films about Soviet agents demonstrated the post-war celebratory moods in the Soviet society: happiness at the end of the war and the Great Victory, belief in the flourishing future which should come after the war sufferings. The other reason was that during the war time the Soviet propaganda formed absolutely positive image of the United States, Great Britain, the antiNazi resistance in France and in other countries of Europe. Friendly feelings of the Soviet people to the allies were strengthen by the mutual cooperation during the war: Soviet-French battalion "Normandy-Neman", Arctic convoys to Murmansk and Archangelsk, participants of Spanish international brigades and German anti-Fascists in the Soviet partisan and diversionist groups. The Soviet film-makers even at the height of the Cold War shot the films and nostalgic songs about the international armed brotherhood of the Soviet and Western combatants during the allEuropean struggle against the Nazis.

With the beginning of the Cold War, those who recently were "armed friends", increasingly became the "enemies", but it was difficult to explain a transition from the Soviet media admiration of allies to their condemnation. Therefore, the post-war driftage of the image of the 
former allies from friendly to a hostile required not only political, but also certain moral explanations in the Soviet mass audience. The film Encounter at the Elbe ${ }^{19}$ by Grigory Alexandrov can be considered as such an artistic explanation. The film tells us about the beginning of the American-Soviet relations in the post-war Germany just after the end of the war on the example of two German neighbor cities and beginning of the "spy game" of the American intelligence service against the Soviet Union. The image of both the Western enemies and allies ceased to be homogeneous in the film: the Germans were shown not as "fascists", but as misinformed victims of the Nazi propaganda. Americans were also pictured in a different way (according to the class ideology and the war ethics): those who remained committed to the ideals of the allied brotherhood were portrayed as positive characters (for example, the commandant of the American sector), but representatives of the American aristocracy and CIA agents were depicted as enemies. The film itself and the prima-actress Liubov' Orlova have received the Stalin Prize for that film, and it demonstrated "ideological correctness" of that film in the eyes of the Soviet government. Another Soviet spy movie which was awarded with the Stalin Prize in 1951, was The Secret Mission ${ }^{20}$ and it was devoted to the operation of the Soviet secret service to prevent the secret operation "Sunrise-Crossword", the separate negotiations between German and Western Allies behind the Soviet Union. The Soviet agents were presented there as the brave and patriotic heroes who risking their lives fought for the justice and the post-war interests of the USSR.

The Soviet cinema 1940-1950s was a single-piece product, due to it only few films were coming out, despite the considerable interest of the Soviet mass audience. The limited production of the Soviet films during Stalin's rule was stipulated by the fact that Stalin believed that cinema industry was an extremely important state matter, and he often personally studied the plans for the new films, controlled the production of the film from the idea and to the script work. The Soviet studios released much more films after the death of Stalin and beginning the "Thaw" (Ottepel'), when the cinema became the most popular and accessible entertainment of the Soviet people. "Thaw" was a period of the political liberalization in the USSR, softening censorship in cultural politics, opening new themes in literature, such as experience of GULAG (in novels by A. Solzhenitsyn, Y. Dombrovsky), widening specter of the genres in the Soviet cinema. The "Golden era" of the Soviet spy genre has started since the 1960s, the most famous and classical movies were created during that period. The spy detective gave a space for hidden allusions to depict political confrontation between the USSR and the Western bloc, which could not be discussed openly in the Soviet mass audience.

The specificity of the Soviet spy movies of the 1960-1970s was that the post-war Soviet spy films can be identified as the "war detectives" because they were devoted to the events of the

\footnotetext{
${ }^{19}$ ALEXANDROV, Grigory, Encounter at the Elbe, Mosfilm, USSR, 1949, 104'.

${ }^{20}$ ROMM, Mikhail, The Secret Mission, Mosfilm, USSR, 1950, 98'.
} 
recent war when the main opposition was the struggle of Soviet people against Nazis. The Soviet spy was fighting against the Nazis at the beginning of the creation of the "spy genre" in the Soviet Union, and it acquitted any spy's behavior. Despite the Cold War and the opposition between Soviet and Western blocks, the majority of the Soviet spy films of the Cold War continued to refer to the opposition between the Soviet and German intelligence services during the World War II or cooperation of the Soviet agents with the European resistance. The issue of the World War II as the "Good War" was always popular in the Soviet culture, that is why it was necessary to fight against the Nazis and to destroy them, as if it "sanctified" and justified any sabotage operation, any violence or severity of spies, not only towards the enemy, but even towards its own Soviet agents or ordinary people who could occasionally be in the circle of the espionage or saboteur operation. Using realities of the World War II as a background for the espionage intrigue, the Soviet spy cinema performed several important functions: the Soviet cinema was based on the doctrine of historical authenticity, and the experience of real Soviet agents and their secret operations of the Cold War time could not be revealed to contemporaries. The artistic reference to the war past as if legitimized the opposition of the Soviet agent and his implacable Western enemies. At the same time the reference to the World War II allowed to use an adventurous plot and hint at the realities of secret service activity.

As an example of such a combination of the ideology of the Cold War and the plot from the World War II would be the spy novels of Vasilij Ardamatskii Counterblow (1959) and "Saturn" is almost invisible (1963) which were successfully screened in three spy films: The way to "Saturn"21, The End of "Saturn"22, and The Battle after Victory". These films were devoted primarily to the Soviet intelligence operations against the Nazis and the Western secret services in the first post-war years. The intrigue was focused on the secret center for training commandos against the Soviet Union, and Western emissaries tried to use Nazi collaborators and Soviet prisoners of war as the training enemies of the post-war Soviet country. The issue of the Soviet prisoners of war was one of disputable subject matters in the Soviet mass-media during the Cold War, because the Soviet POWs were considered as the "potential enemy' agents" in the post-war Soviet official culture. Some Soviet people who were captives in the Nazi concentration camps or survived on the territories occupied by Nazi, were suspected either in espionage, or treachery, or collaboration ${ }^{24}$. They were considered as the "ambivalent" Others in the Soviet official culture, as the former "own" but turned into "alien" for the Soviet state. Another ambivalent Others in the Soviet

\footnotetext{
${ }^{21}$ AZAROV, Villen, The way to "Saturn", Mosfilm, USSR, 1967, 78'.

${ }^{22}$ AZAROV, Villen, The End of "Saturn", Mosfilm, USSR, 1967, 91'.

${ }^{23}$ AZAROV, Villen, The Battle after Victory, Mosfilm, USSR, 1972, 156'.

${ }^{24}$ REINHARD, Otto, The Fate of Soviet Soldiers in German Captivity In: The Holocaust in the Soviet Union. Collection of papers, Washington DC, United States Holocaust Memorial Museum, Center for Advanced Holocaust Studies, 2005, pp. 127-138.
} 
official culture were Russian emigrants (especially, members of the White movement, who struggled against the Bolsheviks during the Civil war in Russia, 1917 - 1922). Both of that cultural and ideological "Others" were not presented in the Soviet war films but they were depicted in the Soviet spy films of the Cold War.

\section{Fate of agent as a drama: a new look at Russian history in Soviet spy cinema of 1960-1980}

Several significant spy films appeared on the Soviet screen in 1968, they were The Shield and the Sword ${ }^{25}$, The Secret Agent's Blunder ${ }^{26}$, and Dead Season ${ }^{27}$. Each of these films has become a cultural event and contributed to the genre of the Soviet "spy movie". The difference between them was that The Shield and the Sword was closer to the genre of "military adventures" about a heroic Soviet spy Belov who was an agent "under cover" inside Germans, while The Dead Season and The Secret Agent's Blunder used the motives of the World War II only as a precondition of the spy narrative, and the main intrigue was built as a classic spy story about the confrontation between Soviet and Western intelligence services.

The historical allusions on the Cold War secret operations were presented in Dead Season, where some facts from biographies of the famous Soviet "sleeper agents" of the Cold War time Rudolf Abel (Fisher) and Konon Molody (known in the Great Britain as Gordon Arnold Lonsdale), - were used. These agents were arrested as a result of the betrayal and convicted by courts in the Western countries (in the USA and Great Britain) for long terms; after several years of imprisonment both of them returned to the Soviet Union as a result of the exchange of the arrested agents between Western and Soviet intelligence agencies. Abel's exchange took place on the Glienicke Bridge in West Berlin, which later became famous as the Bridge of Spies. The movie episode of the agents exchange on the bridge in the film Dead Season became a classical part of the Soviet spy cinema and conveyed the atmosphere of the Cold War as a general distrust and emotional detachment. The history of the Soviet spy Konon Molody (Londsdale) acquired a wide popularity as part of the "spy scandals" of the 1960th: being a Soviet illegal resident spy and the mastermind of the Portland Spy Ring, he was a very successful British businessman and a millionaire. After his discovery and arrest the British film Ring of Spies ${ }^{28}$ was based on Lonsdale's biography.

\footnotetext{
${ }^{25}$ BASOV, Vladimir, The Shield and the Sword, Mosfilm, USSR, 1968, 325'.

${ }^{26}$ DORMAN, Veniamin, The Secret Agent's Blunder, Gorky Film Studios, USSR, 1968, 202'.

${ }^{27}$ KULISH, Savva, Dead Season, Lenfilm, USSR, 1968, 138'.

${ }^{28}$ TRONSON, Robert, Ring of Spies, British Lion Films - Paramount Pictures, United Kingdom, 1964, 90’.
} 
The originality of the Soviet film Dead Season, in my opinion, opens some details of routine "spy job": these are patience, self-discipline and belief, which are especially necessary in the situations of "breakdown", uncovering of an agent. The risk of the spy profession lies not in the possibility of a betrayal at any time, or a failure and agents' death, but also in the fact that even the highest selfdiscipline and good fortune does not guarantee survival after arrest. In particular, Rudolf Abel was released from prison, but it was not typical for the Soviet secret service of 1930-1940s which did not struggle for own arrested agents and did not save them. The story of the brilliant Soviet spy Richard Sorge who was executed in a Japanese prison during the World War II, is demonstrative in this case. The Soviet Union denied Sorge's connection with the Soviet secret service for about a quarter of the century. Only after the release of the movie Who Are You, Mr. Sorge ? $^{29}$, the Soviet government recognized Sorge's feat and awarded him posthumously with the highest military title of the Hero of the Soviet Union (1964). Rudolf Abel was more successful in comparison with Sorge, and he was the first Soviet agent who was exchanged and returned to the USSR after his discovering in Western country.

The Soviet spy movies The Secret Agent's Blunder ${ }^{30}$, The Resident's Fate ${ }^{31}$, Returning of the Resident ${ }^{32}$ and The End of Operation "Resident" ${ }^{33}$, were based on V. Vostokov and O. Shmelyov's novels of the same title, they are of great interest as vivid examples of the spyware genre where some elements of espionage training, human source screening and agent recruitment were shown. The filming of new parts about the Soviet agent Tuljev during 18 years was due to the extreme popularity of the first films in the Soviet mass audience, as well as the emergence of new topics that became actual in the Soviet public consciousness. All those films depicted some details of espionage job. For example, the film The Secret Agent's Blunder shows how the Western intelligence agencies recruited the agents in the post-war Soviet Union, it is a typical enlistment ${ }^{34}$ : money, or blackmail, or provocation for sexual contact and then, forcing a person to carry out orders of intelligence. The Soviet people who collaborated with the Nazis during the war and escaped punishment for it after the war were described as the first source for recruiting agents; the fear to be discovered forced those people to conduct new betrayals. The second source, (as it was depicted in the Soviet spy movies of the 1970-1980s), are the criminals who are primarily interested in money and ready to do anything to get it. The third source is hidden opponents of the Soviet system. Thus, the film The Secret Agent's Blunder reproduces the Soviet propaganda schemes of the Cold War and performs ideological functions. However, the actors who portrayed the recruited agents played a

\footnotetext{
${ }^{29}$ GIAMPI, Yves, Who Are You, Mr. Sorge? Cinétel, Cité Films, Cormoran Films, Jolly Film, Pat, Shôchiku Eiga, Silver Films, Terra Films, France-West Germany-Italy-Japan, 1961, 112'.

${ }^{30}$ DORMAN, Veniamin, The Secret Agent's Blunder, Gorky Film Studios, USSR, 1968, 202'.

${ }^{31}$ DORMAN, Veniamin, The Resident's Fate, Gorky Film Studios, USSR, 1970, 157'.

${ }^{32}$ DORMAN, Veniamin, Returning of the Resident, Gorky Film Studios, USSR, 1982, 129'.

${ }^{33}$ DORMAN, Veniamin, The End of Operation “Resident”, Gorky Film Studios, USSR, 1986, 145'.

${ }^{34}$ CROWDY, Terry, The Enemy Within. A History of Espionage , Oxford - New York, Osprey, 2006.
} 
psychological complex of complicated feelings: fear, remorse, humiliation, resentment, despair, and due to this fact the Soviet spectators could feel some pity to those people. The drama of people who have to be "agents" against their will was first shown in the Soviet cinema. The film was an attempt to romanticize the work of the Soviet secret and counterspy services and to show that KGB defends the Soviet citizens against the Western provocations and the political intrigues abroad.

The main character of films about the "Resident" was an intelligence service officer Michael Tuljev who was born in a Russian aristocratic family which emigrated from Russia to Western Europe after the Bolshevik revolution. The Russian emigrant and Western spy Michael Tuljev came to the Soviet Union as a resident of the Western intelligence agency (with allusions on Western Germany and the USA simultaneously) and voluntarily moved to the Soviet counterespionage service. The theme of emigration took a significant place in those films because, in my opinion, they reflected the true cultural discourses in the USSR during the period of the Cold War, such as opposition of the Soviet intelligentsia towards the government. The spy movies of the 1960-1970 demonstrate the liberalization of the state attitude to the Russian aristocrats and noble families who fled from the Bolshevism to the Western Europe or the USA. This liberalization can be explained by the political and cultural post-war reasons: some Russian emigrants fought against the Nazis in the European resistance. It was impossible to deny the contribution of the Russian emigrants to the anti-Nazi struggle even for the reason that many of the Russian immigrants occupied high positions in the Western political establishment and could support the Soviet political initiatives, expanding the Soviet influence. The cinema plot in which the former emigrant Tuljev, a Russian nobleman, a professional secret service officer, came over to the Soviet counter-espionage service, is symptomatic for the Soviet cinema of that time: it can be seen as a symbolic call of the Soviet authorities to the Soviet intellectuals, who preferred to be in opposition, to cooperate with the Soviet political system. The image of Tuljev, who had passed a difficult way from the enemy of the Soviet authority to the loyal Soviet officer of the secret service security, was aimed at strengthening patriotism inside the Soviet society during the Cold War, showing the Soviet audience that even former enemies of the Soviet state go over to the Soviet side just because of their love to Russia. So, these films were not only about the battle between the Western and the Soviet secret services, but more about the relations of the Soviet state and the Soviet opponents inside the USSR. As Sabine Hake notes ${ }^{35}$, both Soviet agents Belov (from The Shield and the Sword) and Tuljev (from The Secret Agent's Blunder), as a legendary Stierlitz (from Seventeen Moments of Spring) who became the heroes in the Soviet mass

\footnotetext{
${ }^{35}$ HAKE, Sabine, Screen Nazis: Cinema, History, and Democracy, Madison, University of Wisconsin Press, 2012.
} 
consciousness, represented the "ideal Soviet man": rational, but still soulful, deeply patriotic, embodiment of duty and service for Motherland.

The climate of the Cold War was shown in the movie The End of Operation "Resident" in the situation devoted to the spy games around the Soviet nuclear physicist Nesterov, whose figure had clear allusions to the figure of a well-known Soviet physicist and dissident Andrei Sakharov during his exile in Gorky city. Other essential aspects of such films were in showing the professional relations in the security services: for example, the films showed the recruiting of informants and sabotage performers, as well as the principles of agents' verification who "came from in the cold"; that film first demonstrated the procedure of the "lie detector's" work; everyday intrigues in the spy agency and the permanent suspicions on each other were also depicted. The films about Tuljev contributed to the ideological matrix of the Cold War time, because all Soviet officers were portrayed as good, honest, sincere people who did their hard work for the defense of the homeland, while all Western officers of secret service were depicted as dishonest people and often as the Nazi criminals in the past.

Despite the ideological filling, those spy films were extremely successful on the Soviet screen: the ideology was skillfully hidden in the complicated spyware intrigue and adventure plot. Every part about the Soviet spy Tuljev presented first some professional details of the intelligence and counterintelligence job for the Soviet spectators. The first image of the Foreign Legion was represented in the film (Return of the Resident and The End of Operation "Resident") for the Soviet audience. It was a completely new phenomenon for the Soviet culture: to humanize those who were portrayed in the Soviet propaganda as «predators of imperialism» and «soldiers of fortune».

\section{The Soviet spy Stierlitz as the "Cultural Hero" in the Soviet mass consciousness}

The most famous Soviet secret service officer of the Cold War was Stierlitz (SSStandartenführer Max Otto von Stierlitz on the Soviet screen), a spy-intellectual from the extremely popular Soviet TV series Seventeen Moments of Spring ${ }^{36}$, who had been infiltrated into the German secret service many years before the World War II. The film was based on the novel with same title written by the Soviet political and spy detective writer Yulian Semyonov, author of the many Soviet bestsellers. Semyonov was a recognized Soviet novelist, journalist, screenwriter, and during his lifetime there were talks that he had either been closely linked with the KGB or even undercover KGB officer (colonel). Semyonov himself always rejected the questions about his connections with KGB but his way of life suggested such thoughts: when the majority of the Soviet

\footnotetext{
${ }^{36}$ LIOZNOVA, Tatyana, Seventeen Moments of Spring, Gorky Film studio, USSR, 1973, 840'.
} 
people lived behind the Iron Curtain and had a little opportunity to travel abroad, Semyonov regularly traveled to Western Europe, met with Western businessmen, Italian mafia, Russian aristocrats-émigrés and Nazi criminals which, of course, was hardly possible without the authorization of the KGB. For example, Semyonov became widely known in the Soviet Union as a journalist who in 1974 managed to interview a Nazi war criminal Otto Skorzeny, who had categorically refused to meet any journalist before. Then, being a correspondent in West Germany, Semyonov succeeded to interview the former reichsminister Albert Speer and one of the SS leaders Karl Wolff. So, Semyonov himself was perceived in the Soviet mass consciousness as a kind of mediator between the world of ordinary people and the Soviet secret service, making visible the mechanisms of espionage operations and the "big policy".

The novel Seventeen Moments of Spring to have been inspired by a personal request of the KGB chief Yuri Andropov to Yulian Semyonov to write a novel about a Soviet spy who would strengthen the positive image of Soviet secret service in the Soviet mass consciousness. Politically, it should be a Soviet answer to the popularity of the Western spy Bond, but it has to be the "Soviet Bond". Semyonov met to Andropov's demands, and after working in the archives of the KGB wrote a dynamic novel two weeks later. (We can note that Semyonov fulfilled the KGB require successfully and created the image of a Soviet agent who, by his popularity in the Soviet audience, far surpassed all Western super-spies). The character of Stierlitz reflected Andropov's own concept of the ideal Soviet secret service officer: he is to be rational, modest, absolutely loyal to his own country and above all he has to be an intellectual, who had his mission by outwitting his enemies. Distinct from Bond, Stierlitz was not a playboy and adventurer, psychologically he was closer to a mathematical researcher, or to a classic British detective: he was a cold rationalist but resourceful investigator as Sherlock Holmes. Stierlitz became a favorite hero of the Soviet mass audience, he embodied the best qualities of a Soviet intellectual, but intellectual who was not defenseless in a face of the state power but who had special abilities to defend his close people and to serve for the state.

Describing Stierlitz's biography, Semyonov used some facts from biographies of several Soviet agents (in particular, SS-Hauptsturmführer and Soviet informer Willy Lehmann ${ }^{37}$ ) who held high positions in the German Gestapo during the World War II and were Soviet informers. The plot of novel develops around the American-German negotiations on separate peace without the participation of the Soviet Union. They took place in the spring 1945 in Switzerland between the head of the American secret agency Allen Dulles and the German General Karl Wolff and was

\footnotetext{
${ }^{37}$ COPPI, Hans, Willy Lehmann, in SCHAFRANEK, Hans, TUCHEL, Johannes (hrsg.), Krieg im Äther. Widerstand und Spionage im Zweiten Weltkrieg, Wien, Picus Verlag, 2004; ГЛАДКОВ, Теодор, Король нелегалов, [GLADKOV, Teodor, King of illegals], Москва, Гея Итэрум, 2000; СТАВИНСКИЙ, Эрвин, Наш человек в гестапо. Кто вы, господин Штирлиц? [STAVINSKY, Erwin, Our man is in the Gestapo. Who are you, Mr. Stirlitz?], Москва, ОЛМА-Пресс, 2002.
} 
titled "Sunrise Crossword". According to the plot the Soviet super-agent Stierlitz destroyed the separate peace between the Germans and the Western Allies by a complicated intrigue. It should be noted that this conspiracy plot about the prevention of the separate negotiations at the end of the World War II was used by the Soviet filmmakers in earlier Soviet film The Secret Mission.

Soviet director Tatyana Lioznova from the Gorky Film Studio desired to shot the Semyonov's novel as a 12-part TV film and that process took her about two years. Many episodes were shot in East Germany and some East German actors were involved in the film. Especially, German actor Fritz Diez played a role of Adolf Hitler because no Soviet actors wanted to play that role. The work on the series was supervised by the KGB: Andropov's deputy, Colonel General Semen Tzvigun served as a chief consultant, alongside other high-ranking officers of the service. He demanded that some changes in the plot should be made, however, Tzvigun died just before the film premier, and the film came out in Lioznova's redaction.

Some Western scholars wrote that Seventeen Moments of Spring was a typical product of the antiWestern modes in the Soviet society during the Cold War because the central intrigue of the film lay around the treachery of the Western Allies ${ }^{38}$. But the most significant fact is that in spite of the Cold War ended more than twenty five years ago and the Soviet Union collapsed, the film continues to be popular among very different people, generating a big post-Soviet cultural industry of memes, urban and Internet folklore, computer games and computer programs, TV and literary parodies, documentaries about the actors and the history of the creation of film, and even complete literary biography of Shtierlitz as a reconstruction of his life from all Semyonov' books about him ${ }^{39}$. I think that such higher popularity of Shtierlitz in the mass audience can be accounted for by multiply of his image: Shtierlitz's behavior as a combination of Victorian gentleman's intelligence and Soviet patriotism, aristocratic manners and care for those who were weaker (children, women, elders). For example, one of the impressive episodes in the film was a conversation between Shtierlitz and a stray dog and feeding it. Another human nature of the Shtierlitz was his gentle, almost family attitude to an old German woman whose sons died at the front. It is important to note that unlike the "ideal" Western spy Bond, the Soviet Shtierlitz has no passions for gain, women, luxurious life, gambling or money: he embodies the Soviet variant of the "aristocrat of the spirit and duty" in the best traditions of Victorian gentlemen created by the imagination of R.L. Stevenson (Dr. David Livesey in "Treasure Island"), A. Conan-Doyle (Dr. Watson in stories about Sherlock Holmes) or Agatha Christie (Major Hastings in the novels about

\footnotetext{
${ }^{38}$ LOWELL, Steven, In Search of an Ending: Seventeen Moments and the Seventies, in KOENKER, Diane, GORSUCH, Anne (eds), The Socialist Sixties: Crossing Borders in the Second, Bloomington:, Indiana University Press, 2013, pp. 303-322.

${ }_{39}$ CEBEP, Александр, Все о Штирлице. Информация к размышлению [SEVER, Aleksandr, All about Stirlitz. Information for consideration], Москва, Яуза, Эксмо, 2009; ГОРЬКОВСКИЙ, Павел, Расшифрованный Исаев [GORKOVSKY, Pavel, Decoded Isayev], Москва, Яуза, Эксмо, 2009.
} 
Hercule Poirot). Nobility and reliability, despite the profession of a spy, are the parts of the true nature of Shtierlitz.

But it was the external level of the TV film. Many scholarly works have been devoted to the inner structure of the film ${ }^{40}$ and the common opinion of the scholars was that the spy intrigue was just a plan of expression in that movie (using semiotic terminology), while the plan of content was the image of the Nazi bureaucracy which reflected the system of the Soviet political bureaucracy ${ }^{41}$. Not only Soviet, but the post-Soviet intelligentsia comprehended the film in such plural meaning, and this multiplicity of meanings guaranteed a long life of the series. The professional spy became a symbol of the opportunities to survive for any person in the situation of political lack of freedom, bureaucratic pressing or any unbearable life circumstances.

\section{Conclusions}

I conclude that the Soviet spy and the counterspy agent were presented as an "ideal man" in the Soviet spy films, and many Soviet spy films have kept their "cult" status in the post-Soviet audience until now. The history of espionage and own secret service as an important part of the state machinery's functioning was a kind of a taboo in the Soviet Union for a long time. There were rare and short popular articles published in the newspapers about the courageous fighters of "the invisible front" in the Soviet time ("the Invisible Front" was the Soviet propaganda metaphor for depicting the Soviet agents' job). I can pose that the attractive quality of the spyware detectives for the Soviet audience was that this genre as if cracked open a veil of secrecy over such absolute secret things in any state as agents training, the development of espionage operations abroad and even some top secrets of the "big policy". The Soviet spy movie was one of a few opportunities for the Soviet people to look behind the Iron Curtain, but also to consider the inner mechanism of the Soviet power through the cinema metaphors.

The Soviet spy film of the Cold War played ideological functions, creating a positive image of the Soviet spy and counterspy agents and the Soviet intelligence service (ChK - NKVD - KGB); the representatives of the Western countries were described in accordance with the stamps of the

\footnotetext{
${ }^{40}$ NEPOMNYASHCHY, Catharine, «The Blockbuster Miniseries on Soviet TV: Isaev-Stierliz, the Ambiguous Hero of Seventeen Moments in Spring», in The Soviet and Post-Soviet Review, 29, 2002, pp. 257-276; PROKHOROVA, Elena, Fragmented Mythologies: Soviet TV Mini-Series of the 1970s, University of Pittsburg, Doctoral Dissertation, 2003, URL: < http://d-scholarship.pitt.edu/8019 > [consulted on 14 july 2017].

${ }_{41}$ ЗАЛЕССКИЙ, Константин, Семнадцать мгновений весны: Кривое зеркало Третьего рейха [ZALESSKY, Konstantin, Seventeen Moments of Spring: The Curved Mirror of the Third Reich], Москва, Вече, 2006; ЛИПОВЕЦКИЙ, Марк, Искусство алиби: “Семнадцать мгновений весны” в свете нашего опыта [LIPOVETSKY, Mark, The art of the alibi: "Seventeen Moments of Spring" in the light of our experience], in Неприкосновенный запас, 3/2007, URL: < http://magazines.russ.ru/nz/2007/3/li16.html\#_ftn1 > [consulted on 14 july 2017].
} 
Soviet official propaganda: the capitalists were presented as enemies of the Soviet state, while the ordinary citizens of the Western countries bleed for the Soviet agents in those Soviet spy movies. However, later a Soviet spy movie often reflects the social and political problems of the Soviet society which were not discussed openly in media or in the cinema of other genres (for example, the issue of Russian emigration and desire of the Soviet state to establish relations with it; the post-war fate of Soviet prisoners of war; the relationships between Soviet power and Soviet intelligentsia or Soviet dissidents). The struggle between different secret services often had a metaphorical meaning in the Soviet cinema and the spy could symbolize various types of the dual or multiple identity in culture: exile, emigrant, intellectual, national or gender minority. The figure of the spy in the Soviet cinema in the metaphorical form embodied the contradictions that existed in the Soviet society and relations between an individual, society and state.

If the early Soviet spy films were created as the "advertising image" of the Soviet secret agent, as a person without any psychological dramas and doubts, the Soviet spy since the 1960s has created the image of a Soviet spy as intellectual and intuitive person with difficult fate. The tragic motives in the picturing of the Soviet agents had been developing in the Soviet spy films since the Thaw (1960s), when the image of a just lucky agent (created in the film The Secret Agent) was transferred to the suffering agents as a result of the agent's mistake or treachery.

I can assert that the Soviet spy film of the Cold War, despite its ideological tasks, performed a significant emancipatory function in the Soviet mass culture and implicitly liberalized the Soviet consciousness. This feeling appears after viewing a large number of the Soviet spy films which were devoted much of the screen time to depicting Western life and its comfort details, doing it with liking and even nostalgia. Traveling abroad for the majority of ordinary Soviet people was extremely difficult during the Cold War, although the interest to the Western world was common. So, the spyware movie allows the Soviet viewers to see at least fragments of that distant and forbidden world. From the logical point of view, the detailed visualization of the Western places and people could be explained by the fact that the West was the world where the Soviet spies under cover had to perform their responsible job. But the Soviet spy in those films made friends in the West and participated in the bourgeois social life, never expressing his hatred to the people he lived and worked with for many years. For example, the most famous Soviet spy Stierlitz openly expressed his love to the Germans among whom he had lived for twenty years, and he stressed that he fought against the Nazi state, but not against the German people. Thus, the idealization of the Soviet agent arises through underlining his serving not only for the state, but for the people of his own country. So, the Soviet spy was presented as a man who contributed to the preservation of peace. This is a specificity of the spyware discourses in the Soviet spy cinema.

Since 1970s the Soviet spy films have become more open in picturing the professional training of the spies and the details of the espionage operations: typically, some facts from the biography 
of the former Soviet spy or spy actions were the basis for the Soviet spy film. It was a requirement of the realism in the Soviet cinema of 1960-1980s; but at the same time it was a reference to the true facts from the espionage history which created "a visual" and "a popular" history of the Soviet past (even in transformed forms). As a rule, the consultants for the Soviet spy films were invited from the KGB and they were themselves the former agents or their curators. The names of such consultants were either not mentioned in the captures of the film or they were mentioned under pseudonyms, but these people's advice guaranteed the "authenticity" of the details of the spy job in the Soviet spy films.

Viewers during the premiere of the spy film certainly did not know about the secret advisers from the KGB, but every Soviet spy film contained some professional details of espionage job that could only be known to those who were initiated into this craft. The ordinary Soviet citizens had an opportunity to reconstruct all "espionage occupation" through those details and such an aspect of the spy movies stimulated the creative imagination of the Soviet audience. After some time the authors of the film could freely tell people in their interviews or during their conferences with the spectators that the former agents advised them during the filming. Such attention of the KGB to the spy films was not a secret from the Soviet cinema fans, the secret was only the concrete surnames, positions and other details of agents' professional biographies. Thus, the Soviet spy cinema was mantled in the romantic aura of invisible presence of a real spy, watching spy movie was an opportunity for an ordinary person to look on the secret job, to became a kind of "an eyewitness". This aspect stimulated the popularity of the spy films (especially, among the Soviet intellectuals), even for decades after the film's release.

Many Soviet spy films were adventures only at the outer level, but their inner level presented existential reflections on man's choice of his destiny, boundaries between good and evil, loyalty and betrayal, the priority of family or duty. Such human issues turned many Soviet spy movies from adventurous films into narratives about the history of the generation. of course, good direction and convincing actors' play added popularity to the spy films.

The Soviet spy films, in which a Soviet agent is able to win the Western intelligence service and their representatives, have indirectly shaped the conviction of the Soviet audience that «even one soldier inside the enemy can be a warrior» and as long as the Soviet state has at least one active agent, it retains invincibility. So, the spy or counterspy officer was presented as an "ideal Soviet hero", fearless, brave, intelligent, highly professional and totally patriotic. The ideological discourse of a spy's job turns into the discourse of a cultural and national identity, and it can explain the popularity of the classic Soviet spy films. 


\section{THE AUTHOR}

Viktoria A. SUKOVATAYA is Ph. D. and Doctor of Habilitation in Cultural Studies, professor of Theory of Culture and Philosophy of Science Department, Kharkiv National Karazin University, Ukraine. She published more 150 articles in the area of Soviet and post-Soviet identity, Gender and Visual Arts in Ukrainian, Russian, Byelorussian, Serbian, Romanian, Polish, German, Brazilian, and American journals. She is author of three textbooks and one monograph. She was invited as scholar in different academic centers, including University of Virginia (USA), Lund University (Sweden), Hamburg University (Germany), Free University (Berlin, Germany), University of Bologna (Italy), George Washington University, USA and Berkeley University in California (USA).

URL: < http://www.studistorici.com/progett/autori/\#Sukovataya > 